\author{
A.I. Mantel $^{1}$, I.S. Irgibayeva ${ }^{2}$, I.R. Mukatayev ${ }^{2}$ \\ ${ }^{I}$ Luminescent Materials Research Centre Ltd, Astana, Kazakhstan; \\ ${ }^{2}$ L.N. Gumilyov Eurasian National University, Astana, Kazakhstan \\ (E-mail:wunderucho@mail.ru)
}

\title{
Modification of solar batteries by polymer fluorescent films
}

\begin{abstract}
The article describes a method for studying the effect of silicon solar cells' modification using spectrum shifters, which are polymer films based on polymethylmethacrylate with a thickness of about $4 \mu \mathrm{m}$ with embedded fluorescent dyes. In the process of work there were obtained spectrum shifters containing commercially available fluorescent dyes Solvent Yellow 160, Coumarin 440 and BBQ. Evaluation of the spectrum shifters' influence on the efficiency of a solar battery was carried out by comparing the curve of the external quantum yield and the current-voltage characteristics of the latter before and after the modification. Interpretation of the obtained results was based on the absorption and fluorescence spectra of the obtained spectrum shifters. According to the curves of the external quantum yield, a decrease was established in the efficiency of solar cells after the modification by spectrum switches. It is ascertained that the reason for this decrease is the emerging competition in the absorption of incident radiation between the spectrum switch and the solar battery, and the parameters under which this competition would be minimal were determined. According to the data obtained when measuring the volt-ampere characteristics of the obtained modified solar cells, an insignificant increase in the power of the generated electric current was established. A conclusion is made about the contradiction between the results of experiments on measuring the external quantum yield and currentvoltage characteristics. With a detailed examination of the features of these research methods it was possible to find the cause for these contradictions. The main conclusions were drawn about the nature of the interaction of spectrum shifters with solar batteries, and the main conditions under which this interaction was effective were determined.
\end{abstract}

Keywords: solar battery, spectrum switch, external quantum yield, current-voltage characteristics, absorption, fluorescence, fluorescent dye, polymer film.

\section{Introduction}

The best efficiency of the experimental device obtained under laboratory conditions reached the conversion efficiency of $25 \%$ for the plates of elements on crystalline silicon [1] and $19.5 \%$ for thin-film technologies [2].

There are two principal approaches for increasing the efficiency of solar cells. The first is to improve the electronic properties of existing devices [3-6]. The second is the use of luminescent low-energy spectrum shifters that absorb short-wavelength photons and re-emit them at more favorable wavelengths (in the longwavelength region). Luminescent low-energy shifters are a passive approach that involves the use of a luminescent material in a layer located in front of a photocell.

The most common polymers for this purpose are polymethyl methacrylate (PMMA) [7-9] or polyvinyl acetate $[10,11]$, as well as such inorganic crystalline materials, as $\mathrm{Al}_{2} \mathrm{O}_{3}$ [3] or $\mathrm{SiO}_{2}$ [12]. Various types of glasses [13-15] and organic silicates ORMOSIL $[16,17]$ are also used.

Luminescent materials used for low-energy shifters should ideally demonstrate: the quantum yield of luminescence close to unity; a wide absorption band in the region where the efficiency of photocells is low; high absorption coefficient; a narrow band of radiation coinciding with the maximum effective absorption of the photocell; large Stokes shift to minimize reabsorption; low cost; high photostability.

Organic dyes have relatively high absorption coefficients [18], quantum yield close to one [19], and are easily incorporated into the polymer matrix $[18,19]$. Their disadvantages are narrow absorption bands and a relatively small Stokes shift, which leads to considerable reabsorption [20]. Several dyes can be introduced into one polymer matrix and mixed with one layer to increase the width of the absorption band and increase the Stokes shift [8]. Their photostability is a matter of debate, although there are reports of significant successes in this direction and similar dyes are commercially available [19].

In this paper it is planned to study the effect of polymer spectrum shifters containing organic dyes on the efficiency of solar cells. 


\section{Experimental part}

Reagents. The fluorescent dye Solvent Yellow 160 (SY160) (number CAS: 94945-27-4) was purchased from Jinan Junda Industrial Technical Co. Ltd. Fluorescent dyes 7-amino-4-methylcoumarin, coumarin 440 (C440) (Cat. \# 04400); and 4,4"'-bis[(2-butyloctyl)oxy]-1,1':4',1":4",1'"-quaterphenyl (BBQ) (model number 03800) were purchased from Exciton Inc. [21]. Polymethylmethacrylate, $\mathrm{Mw}=996,000$, purchased from Aldrich (Cat. \# 182265). 1,2-Dichloroethane (DCE), 99+\%, purchased from Acros Organics (Cat. \# 406820010. All reagents were used without pre-treatment. The high optical transparency gel of Smartgel OC431A-LVP was purchased from Nyelubricants (Cat. \# SM120913).

Equipment. The fluorescence spectra were measured on a USB2000 + spectrometer from Ocean Optics. The transmission and absorption spectra were measured on a Cary $5000 \mathrm{UV}-\mathrm{Vis}-\mathrm{NIR}$ spectrophotometer from Varian. The profile and thickness of the films were measured on a Dektak 150 profilometer from Veeco. The measurement of the external quantum yield was carried out on a Bentham 218 analyzer equipped with a Bentham TMc300 monochromator and a Bentham PVE30 photovoltaic characterizer and power supplies for a Bentham 605 xenon and halogen lamp. Volt-ampere characteristics were measured on a Keithley 2400 Sourse meter analyzer complete with a Sun 2000 Solar simulator company ABET technologies.

\section{Preparing of polymer films of polymethylmethacrylate}

$0.5532 \mathrm{~g}$ of polymethylmethacrylate (PMMA) were dissolved in $5.7187 \mathrm{~g}$ of dichloroethane (DCE), and a stock solution with a mass concentration of PMMA equal to $8.82 \%$ was obtained.

Four working solutions of different concentrations were prepared from the resulting stock solution. The proportions of the base solution (m (PMMA in DCE)) and dichloroethane (m (DCE), as well as the concentration of the obtained samples (W (PMMA)) are presented in Table 1.

Ta b le 1

The concentrations of the PMMA polymer film solutions

\begin{tabular}{|l|c|c|c|c|}
\hline Solution & 1 & 2 & 3 & 4 \\
\hline m(PMMA in DCE), g & 0.1207 & 0.2535 & 0.3590 & 0.4832 \\
\hline m(DCE), g & 0.5059 & 0.3673 & 0.2395 & 0.1260 \\
\hline W(PMMA), \% & 1.70 & 3.60 & 5.29 & 7.00 \\
\hline
\end{tabular}

The resulting working solutions were applied uniformly onto the borosilicate glass with a thickness of $1 \mathrm{~mm}$ and an area of $25 \times 35 \mathrm{~mm}^{2}$. The application area is $25 \times 25 \mathrm{~mm}^{2}$, the volume of the applied solution for each sample is $0.4 \mathrm{ml}$. After application, the samples were placed in a draught cupboard to remove the solvent. The resulting films were studied using a profilometer in order to determine their thickness and surface topography. Figure 1 shows the measurements of the profile of all 4 films.

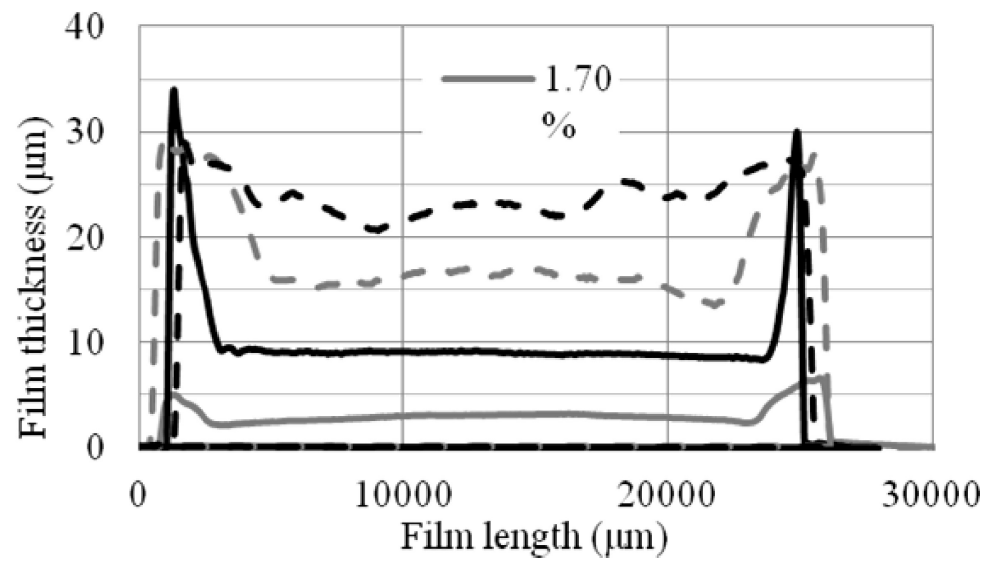

Figure 1. Parameters of the PMMA films profiles obtained from solution in DCE

It can be derived from Figure 1 that the higher is the concentration of the solution from which the film was prepared, the more is the average film thickness, the more is the film thickness, and the worse is its uni- 
formity. It should be noted the presence of sharp ups on the boundaries of films. In calculating the average thickness of the films, these sections are not taken into account.

The average thickness of the films was respectively: $3.05 ; 9.01 ; 16.01 ; 24.0 \mu \mathrm{m}$.

Based on the results obtained, it was decided to adhere in future studies to a solution concentration of about $4 \%$, since it allows to obtain the most uniform film surface at its smallest thickness.

\section{General procedure for introducing phosphors into polymer matrices}

The PMMA solution is divided into four equal parts by weight. Various proportions of the luminophore solution are added to the each part. To all the obtained solutions additions of pure solvent are added in such a way that the total mass of all solutions is the same. The final concentration of PMMA in working solutions is kept at $4 \%$.

\section{Discussion of the results}

At first to the PMMA film was introduced the dye SY160 having the following structure:<smiles>CN(C)c1ccc2cc(-c3nc4cc(Cl)ccc4o3)c(=O)oc2c1</smiles>

As a result of the introduction, a transparent film with a bright yellow-green fluorescence was obtained, containing $2 \%$ of SY160 based on the PMMA mass. The SY160 dye was selected due to its bright fluorescence with a maximum at $495 \mathrm{~nm}$ - the region where the sensitivity of the solar battery is maximal.

The resulting borosilicate glass film was applied to a standard solar cell or solar cell (SC) made of $5 \times 5 \mathrm{~mm}$ polycrystalline silicon by gluing through a gel with a high optical clarity and measuring the External Quantum Yield (EQE) of SC with and without the deposited film. The result is shown in Figure 2.

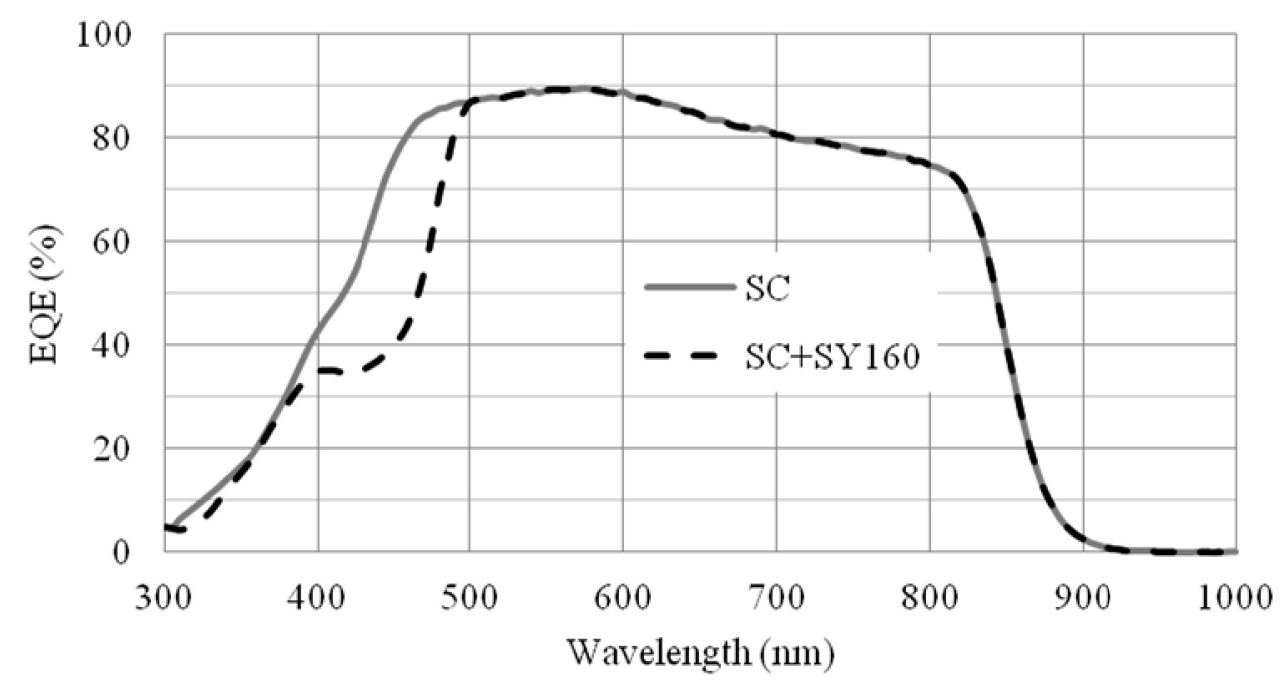

Figure 2. The curves of the BCD of a clean solar cell (SC) and a solar cell covered with a PMMA film containing the SY160 (SC + SY160) dye

As can be seen from Figure 2, the presence of a fluorescent PMMA film with SY160 leads to a decrease in the SC quantum yield in the ranges of 300-360 nm and 390-500 nm. At first glance, the result is contrary to the theory that the EQE SC should have increased in the wavelength region of $495 \mathrm{~nm}$ if a fluorescent film is applied. However, if we consider the absorption and fluorescence spectra of the resulting film (Figure 3), we can explain the obtained result.

As can be seen from Figure 3, the absorption spectrum of SY160 has 2 peaks - from 240 to $340 \mathrm{~nm}$ and from 350 to $500 \mathrm{~nm}$. If we look at Figure 2, it is in these areas that we see a drop in the SC VC. This is clearly seen if we compare the absorption spectrum of SY160 with the curve obtained by subtracting the curve SC + SY160 from the curve SC shown in Figure 4. 


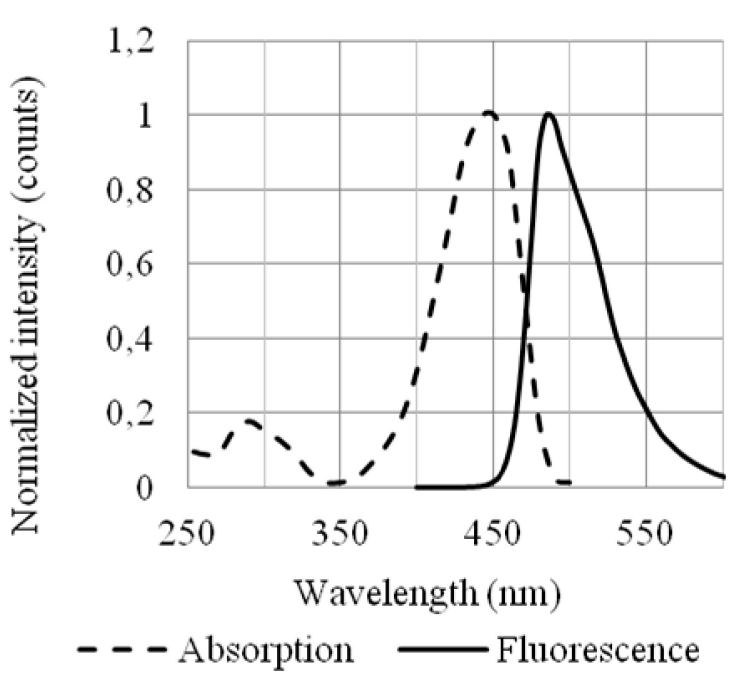

Figure 3. Absorption and fluorescence spectra of the dye SY160

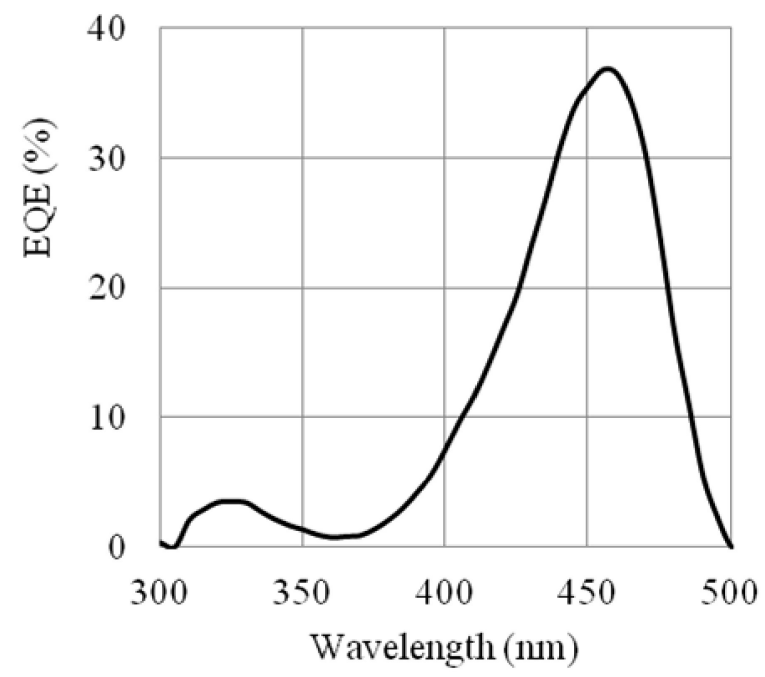

Figure 4. The difference between the EQE SC and SC + SY160 curves from Figure 3

It may seem that in Figures 2 and 3 there is no visible contribution of fluorescence, which should increase the EQE of SC. Comparing Figures 3 and 4, one can see some differences in the ratio of peak intensities and their locations, which is a consequence of the fact that Figure 4 reflects the total contribution from absorption and fluorescence, that is, the difference in absorption and fluorescence intensities at the moment of excitation of the sample at a given wavelength.

From the results obtained, it can be concluded that when light falls on an SC covered with a fluorescent film, a competition arises between the film and SC in absorbing the incident radiation. The SC falls on the radiation that was not absorbed by the film. This competition is the higher, the closer the absorption peak of the dye and the maximum of efficiency are on the SC curve in SC. This loss cannot be compensated by the fluorescence of the film, since the energy absorbed by the film is always greater than the energy transferred to fluorescence or, in other words, the quantum yield of fluorescence is always less than 1.

From the above it follows that as a spectrum shifter for SC it is necessary to use a fluorescent film having an absorption maximum where the EQE SC curve has a minimum.

As fluorophores having absorption in the short-wavelength region of the spectrum, where the EQE SC is the minimum, dyes C440 and BBQ, absorbing shorter than $400 \mathrm{~nm}$, were chosen.

The introduction of dyes into polymer films was carried out according to the procedure described above. For each colorant, 4 films with different weight proportions of the dye in the polymer were prepared. This was done in order to trace the effect of a gradual increase in the concentration of the dye on changes in the EQE SC, as well as to avoid distortion of the results in view of the effect of concentration quenching, which may appear in one of the samples. In this case, the results of this sample will simply not be taken into account.

The first samples of films containing a fluorescent dye C440 were investigated. A summary of the dye is shown in Table 2 .

Table 2

Brief information about the dye $\mathbf{C 4 4 0}$

\begin{tabular}{|c|c|c|c|c|}
\hline Full name & \multicolumn{4}{|c|}{ 7-Amino-4-methylcoumarin } \\
\hline Abbreviation & \multicolumn{4}{|c|}{$\mathrm{C} 440$} \\
\hline \multicolumn{5}{|l|}{ Dye structure } \\
\hline \multirow{2}{*}{$\begin{array}{l}\text { Weight percent } \\
\text { in PMMA films }\end{array}$} & 1 & 2 & 3 & 4 \\
\hline & $1.79 \%$ & $1.11 \%$ & $0.59 \%$ & $0.24 \%$ \\
\hline
\end{tabular}


The absorption and fluorescence spectra are represented by the C440 dye in Figure 5. Figure 6 shows the curves of EQE pure SC, and SC coated with C440 films with a mass concentration of $1.79 \%$ and $0.59 \%$ in the 300-500 $\mathrm{nm}$ range. The remaining $2 \mathrm{nd}$ concentrations are not indicated in order to avoid cluttering the schedule and loss of informative value.

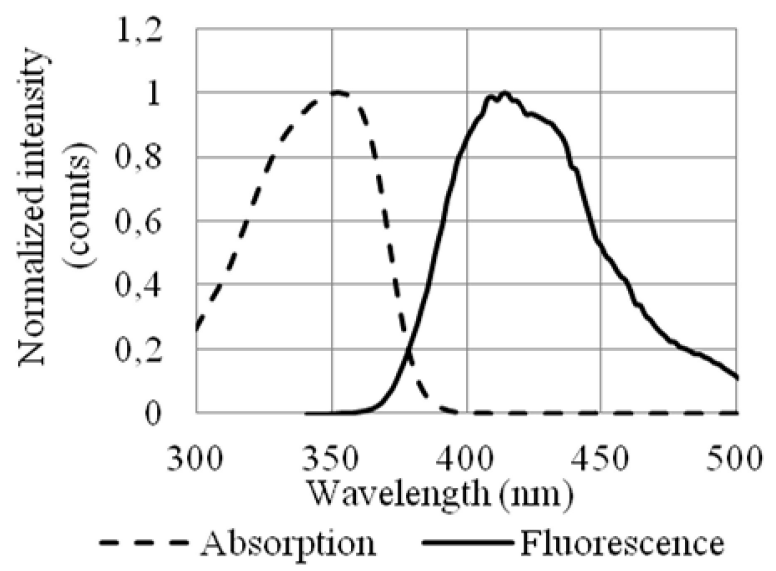

Figure 5. Absorption and fluorescence spectra of the C440 dye

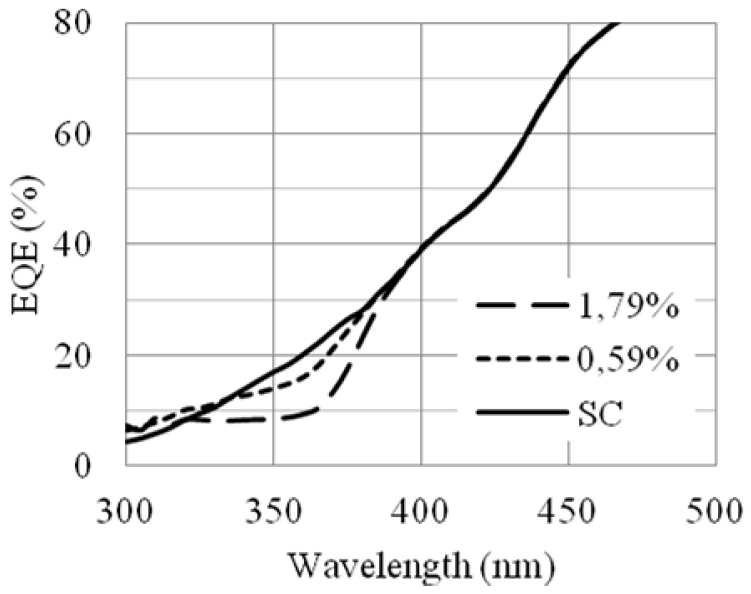

Figure 6. EQE curves of pure SC and SC coated with PMMA films containing C440 dye at concentrations of $1.79 \%$ and $0.59 \%$

It can be seen from Figure 6 that with an increase in the C440 dye concentration, the SC efficiency in the 320 to $390 \mathrm{~nm}$ region decreases. Figure 5 shows that this is the region where the absorption of the dye is located. In the spectral range $300-320 \mathrm{~nm}$, a slight increase in efficiency can be seen, even though in this region the dye has a significant absorption value. This confirms the conclusion made earlier that the smaller the value of the EQE SC in a certain portion of the spectrum, the smaller the fraction of absorbed energy the SC converts into electricity, and the less competition is expressed between the SC and the spectrum switch.

During the research, the current-voltage characteristics of the obtained samples were measured (Table 3).

T a b l e 3

\section{Volt-ampere characteristics of the SC coated with polymer films with C440}

\begin{tabular}{|c|c|c|c|c|}
\hline Sample & Jsc, $\mathrm{mA} / \mathrm{cm}^{2}$ & Pmax, $\mathrm{mB} / \mathrm{cm}^{2}$ & Efficiency, $\%$ & Relative efficiency ${ }^{*} \%$ \\
\hline $\mathrm{SC}$ & -23.60 & -11.10 & 11.10 & 100 \\
\hline $1.79 \%$ & -23.62 & -11.14 & 11.14 & 100.36 \\
\hline $1.11 \%$ & -23.49 & -11.03 & 11.03 & 99.34 \\
\hline $0.59 \%$ & -23.41 & -11.01 & 11.01 & 99.18 \\
\hline $0.24 \%$ & -23.49 & -10.95 & 10.95 & 98.65 \\
\hline
\end{tabular}

Note. ${ }^{*}$ Relative efficiency is calculated from the efficiency of the CS, which is assumed to be equal to $100 \%$.

From Table 3, it is seen that in the case of a concentration of the dye in the PMMA film equal to $1.79 \%$, an insignificant increase in efficiency with respect to the pure CS is observed, which contradicts the data in Figure 6 , where the concentration of the $1.79 \%$ dye leads to the maximum decrease in the CS efficiency. This discrepancy will be considered below.

Hereafter spectrum explorers containing the fluorescent dye BBQ were investigated. A summary of the dye is presented in Table 4.

The absorption and fluorescence spectra of BBQ are shown in Figure 7. The curves of the BCD of a clean solar cell (SC) and a solar cell with overlying PMMA films containing the BBQ dye are shown in Figure 8. 
$\mathrm{Tab}$ a 4

Brief information about the BBQ dye

\begin{tabular}{|c|c|c|c|}
\hline Full name & \multicolumn{3}{|c|}{4,4 "'-bis[(2-butyloctyl) oxy]-1,1':4',1":4",1"'-quaterphenyl } \\
\hline Abbreviation & \multicolumn{3}{|c|}{} \\
\hline \multirow{2}{*}{ Dye structure } & \multicolumn{2}{|c|}{$\left({ }_{2}\right.$} &
\end{tabular}

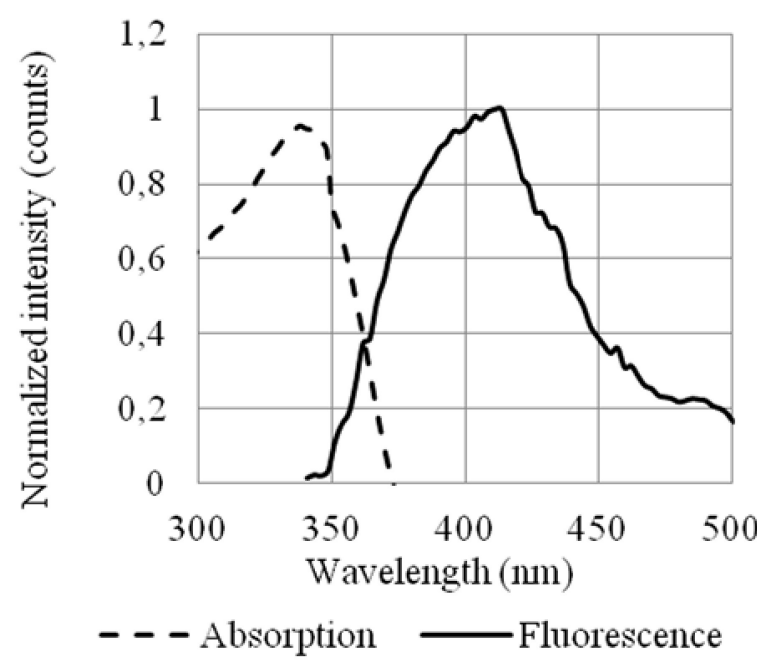

Figure 7. Absorption and fluorescence spectra of the BBQ dye

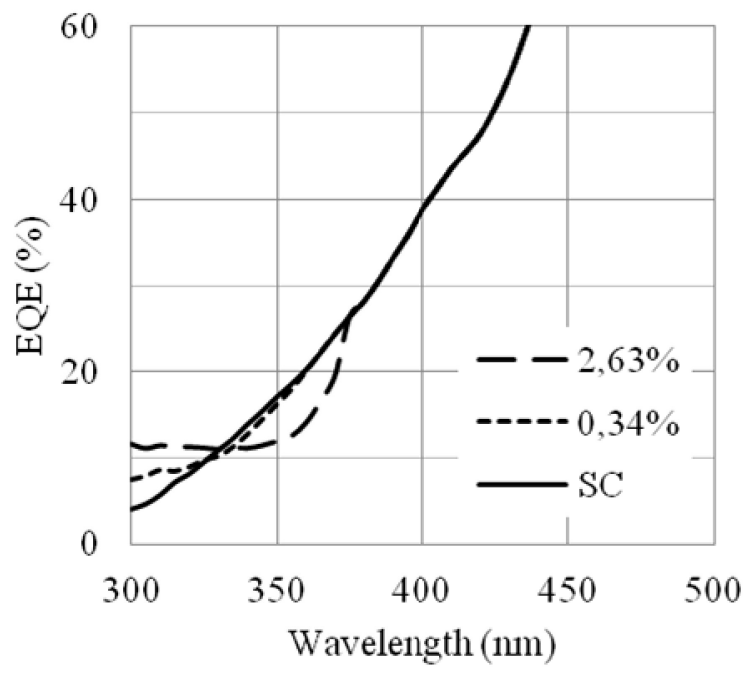

Figure 8. The curves of the DCD of a clean solar cell (SC) and a solar cell coated with PMMA films containing BBQ dye at concentrations of $2.63 \%$ and $0.34 \%$

It can be seen clearly from Figures 7 and 8 that in the $300-320 \mathrm{~nm}$ region the spectrum shifters with the $\mathrm{BBQ}$ dye show the most pronounced increase in the EQE SC and a less pronounced decrease in the EQE SC in the 320 to $390 \mathrm{~nm}$ region compared to the C440. This is because the absorption bands of the BBQ dye lie in a shorter wavelength range than in the $\mathrm{C} 440$, which means that there is less pronounced competition between SC and the spectrum switch. It is expected that measuring the current-voltage characteristics of SC coated with BBQ dye films will show a greater efficiency increase than for samples with C440 dyes (Table 5).

$\mathrm{Tab} l \mathrm{e} 5$

Volt-ampere characteristics of the SC coated with polymer films with BBQ

\begin{tabular}{|c|c|c|c|c|}
\hline Sample & Jsc, $\mathrm{mA} / \mathrm{cm}^{2}$ & Pmax, $\mathrm{mB} / \mathrm{cm}^{2}$ & Efficiency, $\%$ & Relative efficiency ${ }^{*}, \%$ \\
\hline SC & -24.20 & -11.14 & 11.14 & 100 \\
\hline $2.63 \%$ & -23.83 & -11.04 & 11.04 & 99.10 \\
\hline $1.33 \%$ & -23.57 & -10.92 & 10.92 & 98.02 \\
\hline $0.67 \%$ & -23.83 & -11.07 & 11.07 & 99.37 \\
\hline $0.34 \%$ & -23.93 & -11.14 & 11.14 & 100 \\
\hline
\end{tabular}

Note. ${ }^{*}$ Relative efficiency is calculated from the efficiency of the CS, which is assumed to be equal to $100 \%$.

It can be derived from Table 5 that the efficiency of the SC coated with films with BBQ drops with regard to the clean SC for all concentrations of BBQ, which contradicts the results of Figure 5. This contradiction can be explained by the difference in the operation of the instruments for measuring the BAT and voltampere characteristics. 
The device for measuring the EQE registers the energy of the radiation incident on the $\mathrm{SC}$ at a certain wavelength and the energy produced by the SC when this radiation hits it. The device then calculates the quantum yield as the ratio of the energy generated by SC to the energy of the radiation incident on the SC. Thus, the shape of the incident radiation spectrum on SC does not affect the shape of the EQE curve.

In the instrument for determining the current-voltage characteristics, the radiation from the SC is supplied by a simulator of solar radiation, which produces the radiation similar to sunlight. The instrument measures basic SC parameters, which directly depend on the spectrum and intensity of the incident radiation.

Figure 9 shows the emission spectrum from the solar spectrum simulator, as well as the SC absorption spectrum calculated on the basis of the EQE SC.
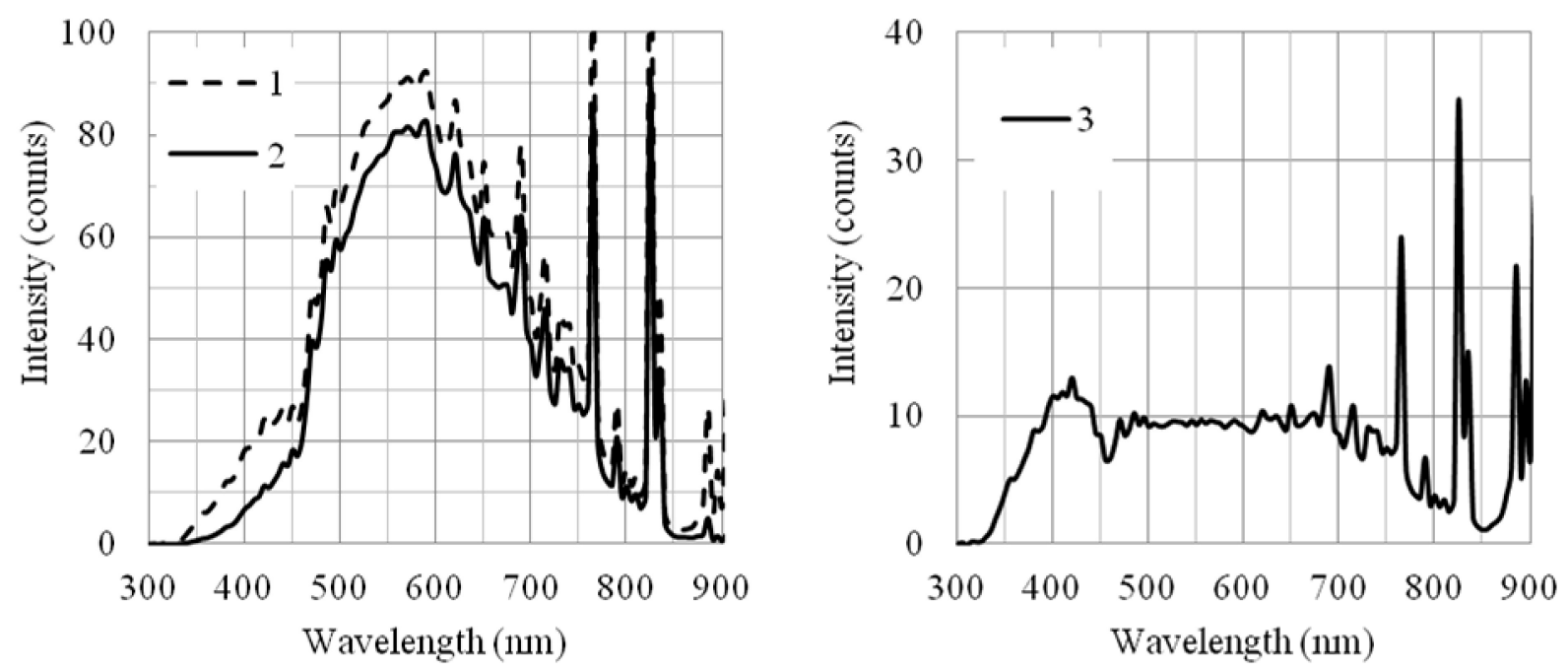

Figure 9. The emission spectrum of the solar simulator (1), calculated on the basis of the BAC, effective absorption spectrum of SC (2) and the difference between spectra 1 and 2 (3)

Figure 9 shows that in the range from 300 to $350 \mathrm{~nm}$, taking into account the low intensity of the incident radiation, as well as the low value of the EQE, the effective absorption of SC is negligible. Since the BBQ dye has an absorbance of up to $350 \mathrm{~nm}$, it is logical that we do not observe any increase in efficiency in the case of spectrum shifters containing BBQ when measuring the volt-ampere characteristics of the samples. If we subtract curve 2 from curve 6 from curve 1, we obtain curve 3 describing the energy of the unused solar battery. The dye BBQ in this case, there is practically nothing to collect, whereas for the C440 dye the absorption spectrum stretches to $380 \mathrm{~nm}$, where there is a larger amount of non-absorbed energy. That is why we see a slight increase in the efficiency of SCs covered by spectrum shifters containing C440, with a simultaneous decrease in efficiency on the BAC curves.

In addition, for some samples there is a slight decrease in efficiency, as can be seen from Table 5, caused not so much by the absorption of the dye as by the scattering of the incident light by the sample.

\section{Conclusion}

As a result of the work, spectra based on the PMMA matrix containing fluorescent dyes SY98, C440, and BBQ were obtained. The influence of these shifters on the efficiency of the solar battery on which they were applied was studied.

As a result of the study, the following conclusions were made:

1) there is a competition between the spectrum switch and the solar battery, expressed in the fact that some of the energy absorbed by the switch does not reach the solar battery;

2) the effect of competition between the spectrum switch and the solar battery is much more pronounced than the effect of increasing efficiency due to fluorescence;

3 ) the absorption region is a more important parameter for the spectrum displacer than the region of its fluorescence;

4) spectrum shifters absorbing shorter than $350 \mathrm{~nm}$ do not affect solar batteries. 


\title{
References
}

1 Green M.A. Solar cell efficiency tables (version 42) / M.A. Green et al. // Prog. Photovoltaics Res. Appl. — 2013. Vol. 21, No. 5. - P. 827-837.

2 Klampaftis E. Enhancing the performance of solar cells via luminescent down-shifting of the incident spectrum: A review / E. Klampaftis et al. // Solar Energy Materials and Solar Cells. — 2009. — Vol. 93, No. 8. — P. 1182-1194.

3 Hovel H.J. The effect of fluorescent wavelength shifting on solar cell spectral response / H.J. Hovel, R.T. Hodgson, J.M. Woodall // Sol. Energy Mater. - 1979. - Vol. 2, No. 1. - P. 19-29.

4 Bedair S.M. A two-junction cascade solar-cell structure / S.M. Bedair, M.F. Lamorte, J.R. Hauser // Appl. Phys. Lett. 1979. - Vol. 34, No. 1. - P. 38-39.

5 Taguchi M. HITTM cells - high-efficiency crystalline Si cells with novel structure / Taguchi M. et al. // Prog. Photovoltaics Res. Appl. - 2000. - Vol. 8, No. 5. - P. 503-513.

6 Luque A. Increasing the efficiency of ideal solar cells by photon induced transitions at intermediate levels / A. Luque, A. Martí // Phys. Rev. Lett. - 1997. - Vol. 78, No. 26. - P. 5014-5017.

7 Maruyama T. Solar cell module colored with fluorescent plate / T. Maruyama, A. Enomoto, K. Shirasawa // Sol. Energy Mater. Sol. Cells. - 2000. - Vol. 64, No. 3. - P. 269-278.

8 Richards B.S. Overcoming the poor short wavelength spectral response of CdS/CdTe photovoltaic modules via luminescence down-shifting: Ray-tracing simulations / B.S. Richards, K.R. McIntosh // Prog. Photovoltaics Res. Appl. — 2007. — Vol. 15, No. 1. - P. 27-34.

9 Slooff L.H. Efficiency Enhancement of solar cells by application of a polymer coating containing a luminescent dye / L.H. Slooff et al. // J. Sol. Energy Eng. — 2007. — Vol. 129, No. 3. — P. 272.

10 Marchionna S. Photovoltaic quantum efficiency enhancement by light harvesting of organo-lanthanide complexes / S. Marchionna et al. // J. Lumin. — 2006. — Vol. 118, No. 2. — P. 325-329.

11 Le Donne A. Enhancement of solar energy conversion efficiency by light harvesting of organo-lanthanide complexes / A. Le Donne et al. // 23rd European photovoltaic solar energy conference and exhibition, 1-5 September 2008, Valencia, Spain. - WIPMunich, 2008. - P. 269-271.

12 Protti S. Wavelength shifting systems based on flavonols and their metal complexes encapsulated by post-doping in porous $\mathrm{SiO}_{2}$ xerogel matrices / S. Protti et al. // Journal of Molecular Structure. — 2011. — Vol. 993, No. 1-3. — P. 485-490.

13 Kawano K. Application of rare-earth complexes for photovoltaic precursors / K. Kawano et al. // Sol. Energy Mater. Sol. Cells. - 1997. - Vol. 48, No. 1. - P. 35-41.

14 Švrček V. Silicon nanocrystals as light converter for solar cells / V. Švrček, A. Slaoui, J.C. Muller // Thin Solid Films. 2004. - Vol. 451-452. - P. 384-388.

15 Yamada K. Improvement of efficiency of solar cells by application of the rare earth ions doped fluorescent glass / K. Yamada et al. // Kidorui (Rare Earths). — 2000. — Vol. 36. — P. 252-253.

16 Machida K. Preparation and application of lanthanide complex incorporated ormosil composite phosphor films / K. Machida et al. // J. Lumin. - 2000. - Vol. 87-89. - P. 1257-1259.

17 Jin T. Photovoltaic cell characteristics of hybrid silicon devices with lanthanide complex phosphor-coating film / T. Jin // J. Electrochem. Soc. - 1997. — Vol. 144, No. 11. — P. 4054.

18 Viehmann W. Thin-film scintillators for extended ultraviolet (UV) response silicon detectors / Ed. H.P. Field, E.F. Zalewski, F.M. Zweibaum // International Society for optics and photonics. — 1979. - Vol. 196. — P. 90-95.

19 Seybold G. New perylene and violanthrone dyestuffs for fluorescent collectors / G. Seybold, G. Wagenblast // Dye. Pigment. - 1989. - Vol. 11, No. 4. - P. 303-317.

20 Sah R.E. Influence of the solvent matrix on the overlapping of the absorption and emission bands of solute fluorescent dyes / R.E. Sah, G. Baur, H. Kelker // Appl. Phys. — 1980. — Vol. 23, No. 4. — P. 369-372.

21 Exciton [ER]. URL: http://www.exciton.com/ (accessed: 04.09.2017).

\section{А.И. Мантель, И.С. Иргибаева, И.Р. Мукатаев \\ Флуоресцентті полимерлердің қабыршақтарымен күн сәулесі батареяларын түрлендіру}

\begin{abstract}
Мақалада флуоресцентті бояғыштар енгізілген, қалыңдығы шамамен 4 мкм, полиметилметакрилат негізіндегі полимерлі қабыршақтар болып табылатын, кремний күн сәулелерінің спектрлі жылжытқыштар көмегімен модификациялаудың әсерін зерттеу әдісі сипатталған. Жұмыс барысында коммерциялық жағынан қолжетімді Solvent yellow 160, Coumarin 440 және BBQ флуоресцентті бояғыштары бар спектрлік жылжытқыштар алынды. Күн батареясының тиімділігіне спектрлік жылжытқыштар әсері сыртқы кванттық шығудың қисық сызығын және модификацияға дейінгі және кейінгі вольтампер сипаттамаларын салыстыру арқылы бағаланды. Алынған нәтижелерді интерпретациялау алынған жылжытқыштардың жұтылу мен флуоресценция спектрлеріне негізделген. Сыртқы кванттық шығудың қисықтарына сәйкес спектрлік жылжытқыштар арқылы модификациядан кейін күн батареяларының тиімділігінің төмендеуі анықталды. Осындай төмендеудің себебі спектралды жылжытқыш пен күн батареясы арасындағы сәулеленудің сіңірілуіндегі пайда болатын
\end{abstract}


бәсекелестік және оның ең аз болатын параметрлері анықталды. Алынған модификацияланған күн батареяларының вольтампер сипаттамаларын өлшеу кезінде алынған деректерге сәйкес, өндірілетін электр тоғының қуаты шамалы көтерілді. Сыртқы кванттық шығу және вольтампер сипаттамаларын өлшейтін эксперименттердің нәтижелері арасындағы қайшылық туралы қорытынды жасалды. Зерттеу әдістерінің ерекшеліктері егжей-тегжейлі қарастырылғанда осы қарама-қайшылықтардың себебі айқындалды. Негізгі қорытындылар күн батареялары мен спектрлік жылжытқыштардың өзара әрекеттесу сипаты және осы өзара әрекеттесудің тиімді болатын негізгі шарттары туралы жасалды.

Кілт сөздер: күн батареясы, спектрлік жылжытқыш, сыртқы кванттық шығу, вольтампер сипаттамасы, сіңіру, флуоресценция, флуоресценциялық бояғыш, полимерлі қабыршақ.

\section{А.И. Мантель, И.С. Иргибаева, И.Р. Мукатаев \\ Модификация солнечных батарей полимерными флуоресцентными пленками}

В статье описан метод исследования модификации кремниевых солнечных батарей при помощи сместителей спектра, которые представляют собой полимерные пленки на основе полиметилметакрилата толщиной примерно 4 мкм с внедренными флуоресцентными красителями. В процессе работы были получены сместители спектра, содержащие коммерчески доступные флуоресцентные красители Solvent yellow 160, Кумарин 440 и BBQ. Оценку влияния сместителей спектра на эффективность солнечной батареи проводили сравнением кривой внешнего квантового выхода и вольтамперных характеристик последней до и после модификации. Интерпретацию полученных результатов вели с учетом спектров поглощения и флуоресценции полученных сместителей спектра. По данным кривых внешнего квантового выхода было установлено снижение эффективности солнечных батарей после модификации сместителями спектра. Установлено, что причина данного снижения - возникающая конкуренция в поглощении падающего излучения между сместителем спектра и солнечной батареей. Кроме того, определены параметры, при которых данная конкуренция была бы минимальной. По результатам измерения вольтамперных характеристик полученных модифицированных солнечных батарей установлено незначительное увеличение мощности вырабатываемого электрического тока. Сделан вывод о противоречии результатов экспериментов измерения внешнего квантового выхода и вольтамперных характеристик. Причина данных противоречий была установлена при детальном рассмотрении особенностей данных методов исследования. Изучена природа взаимодействия сместителей спектра с солнечными батареями и выведены основные условия, при которых данное взаимодействие было бы эффективным.

Ключевые слова: солнечная батарея, сместитель спектра, внешний квантовый выход, вольтамперные характеристики, поглощение, флуоресценция, флуоресцентный краситель, полимерная пленка. 